DOI https://doi.org/10.30525/978-9934-588-81-5-2.3

\title{
МОРФОФУНКЦІОНАЛЬНИЙ СТАН ІНТРАМУРАЛЬНОГО НЕРВОВОГО АПАРАТУ ДВАНАДЦЯТИПАЛОЇ КИШКИ В ІНТАКТНИХ ЩУРІВ
}

\author{
Білінський I. I.
}

асистент кафедри клінічної анатомії та оперативної хірургї

Івано-Франківський національний медичний університет

Федорак Л. В.

асистент кафедри клінічної анатомії та оперативної хірургії

Івано-Франківський начіональний медичний університет

Білінська В. В.

стариий лаборант кафедри клінічної анатомії та оперативної хірургії

Івано-Франківський наиіональний медичний університет

Іванців О. P.

кандидат медичних наук,

асистент кафедри клінічної анатомії та оперативної хірургії

Івано-Франківський національний медичний університет

Попович Ю. І.

доктор медичних наук, професор,

завідуючий кафедри клінічної анатомії та оперативної хірургії

Івано-Франківський національний медичний університет

м. Івано-Франківськ, Украӥна

Вступ. Ентеральна нервова система (ЕНС) - власна нервова система шлунково-кишкового тракту, яка $є$ одним із відділів вегетативної нервової системи та відіграє важливу роль в фізіологічних процесах, що протікають в кишечнику та при їх порушеннях $[1,2]$.

Інтрамуральний нервовий апарат дванадцятипалої кишки добре розвинутий і гістологічно представлений трьома сплетеннями: підсерозним, м'язово-кишковим та підслизовим. Найбільш вираженим є м'язово-кишкове сплетення (Ауербаха) [3, 4]. У вузлах м'язовокишкового сплетення спостерігаються нейроцити овальної, трикутної та веретеноподібної форм, кількістю від 3 до 25 нервових клітин, мають сферичне або овальне світле ядро, що розташовується у центрі клітини або дещо зміщене до периферії. В ядрі у вигляді дрібних гранул розташовується гетерохроматин. В центрі каріоплазми знаходиться одне або рідше два інтенсивно забарвлені ядерця. У цитоплазмі рівномірно візуалізується базофільна речовина у вигляді невеликих 
грудочок і зерен. В нейроплазмі розташовуються цистерни гранулярної ендоплазматичної сітки, мітохондрії, лізосоми [5].

Провівши аналіз вітчизняної та зарубіжної літератури виявлено, що детально вивчені типи нервових клітин у дванадцятипалій кишці і існуючі зв'язки між ними, але менше уваги приділено кількісній та якісній оцінці ступення морфологічних змін нейронів у дванадцятипалій кишці інтактних тварин.

Мета дослідження. Світлооптично встановити морфофункціональні особливості нейронів кишково-м'язового сплетення дванадцятипалої кишки в інтактних щурів.

Матеріал і методи. Дослідження виконано на 10 білих нелінійних щурах-самцях масою 130-180 г. Для гістологічного дослідження нейронів інтрамурального нервового сплетення, шматочки дванадцятипалої кишки фіксували в 96\% етиловому спирті, об'єм якого в 20 разів перевищував об'єм тканини, до від'ємної проби на жир, після чого проводили до парафінових блоків за загальноприйнятою методикою. На санному мікротомі виготовляли зрізи товщиною 5-8 мкм. Гістологічні зрізи забарвлювали за методом Нісля $0.5 \%$ водним розчином крезилового фіолетового.

Морфологічну характеристику стану нейронів інтрамурального апарату дванадцятипалої кишки та виявлені їх зміни позначали в балах, використовуючи при цьому схему Свіщева А.В. (таб.1).

Ступінь змін (С3) нервових клітин в м'язово-кишковому сплетенні визначали за формулою:

$$
\begin{aligned}
& \mathrm{C} 3=\mathrm{C} \times 100 / \mathrm{A}, \\
& \text { де } \mathrm{C}=26+2 \mathrm{~B}+3 \Gamma+4 д+5 \mathrm{e}+6 ж+63 \\
& \mathrm{~A}=\mathrm{a}+\mathrm{C}
\end{aligned}
$$

Таблиця 1

Морфологічна характеристика стану нейронів та їх оцінка в балах

\begin{tabular}{|c|c|c|}
\hline Морфофункціональний стан нейронів & Бали & Умовні позначки \\
\hline Незмінені & 1 & a \\
\hline Гіперхромний & 2 & 6 \\
\hline 3 початковими явищами набухання і хроматолізу & 2 & в \\
\hline 3 вираженими явищами набухання і хроматолізу & 3 & г \\
\hline Вакуолізовані & 4 & д \\
\hline Дегідратовані & 5 & е \\
\hline Атрофовані & 6 & ж \\
\hline Загиблі & 6 & 3 \\
\hline
\end{tabular}

Результати і обговорення. Світлооптично виявляється поліморфізм нейронів інтрамурального нервового апарату дванадцятипалої кишки. У вузлах м'язово-кишкового сплетення знаходиться від 3 до 20 нерво18 
вих клітин. Розміри нервових гангліїв та кількість нейронів тісно пов'язані між собою. Більшість нейронів інтрамурального нервового апарату мають типову будову - незмінені нейрони (79,5\%) (таб. 2). Вони мають овальну або округлу форми, рідше - трикутну або веретеноподібну. Цитоплазма заповнена рівномірно розподіленою базофільною речовиною у вигляді невеликих зерен або грудочок. Ядра нейронів розміщені в центрі або злегка зміщенні до периферії, мають сферичну або овальну форми. У ядрі дифузно, у вигляді дрібних гранул розташовується гетерохроматин. В каріоплазмі знаходиться одне або два інтенсивно забарвлених базофільних ядерця, які знаходяться в центрі або дещо ексцентрично.

У вузлах м'язово-кишкових сплетень зустрічаються нейроцити, стан ядра та базофільної субстанції яких відрізняється від більшості нейронів, що дозволяє говорити про них, як про змінені. Найчастіше зустрічаються нейрони 3 початковими явищами набухання і хроматолізу (9\%), вони мають набрякле та ексцентрично зміщене ядро, дрібнозернисту базофільну речовину, яка набуває дифузного розташування та блідішого забарвлення, а місцями відсутня, рідше - 3 вираженими явищами набухання і хроматолізу (5\%). Окремі нервові клітини мають інтенсивно забарвлені ядра та базофільну речовину - гіперхромні нейрони (4\%). Поодинокі нейрони стають вакуолізованими (1\%), в них виявляють вакуолі. Рідше зустрічаються клітини, які мають подовжену або звужену форми з різко окреслиними контурами, з гіперхромними цитоплазмою і ядром - дегідратовані нейроцити $(0,5 \%)$. Деякі нейрони зі збереженою формою клітини мають малі розміри тіла і ядра. Дуже рідко виявляються атрофовані нейроцити (1\%), навколо яких спостерігається скупчення гліоцитів. Загиблі нейроцити нами не виявлені. Ступінь змін нейроцитів $\left(\mathrm{C}_{3}\right)$ становить $40,23 \%$.

Таблиця 2

\section{Розподіл нейронів м'язово-кишкового сплетення} за морфофункціональним станом:

\begin{tabular}{|c|c|}
\hline Морфофункціональний стан нейронів & \% \\
\hline Незмінені & 79,50 \\
\hline Гіперхромний & 4,00 \\
\hline 3 початковими явищами набухання і хроматолізу & 9,00 \\
\hline 3 вираженими явищами набухання і хроматолізу & 5,00 \\
\hline Вакуолізовані & 1,00 \\
\hline Дегідратовані & 0,50 \\
\hline Атрофовані & 1,00 \\
\hline Загиблі & 0,00 \\
\hline С3 & 40,23 \\
\hline
\end{tabular}


Морфологічні зміни в нервових клітинах інтактних тварин є зворотними і незворотними. До зворотних змін відносяться вогнищевий хроматоліз і набухання, ектопія ядра та ядерця, а до незворотних тотальний хроматоліз, великокомірчаста вакуолізація цитоплазми, різке зморщування або сильне набухання нейронів, каріолізис та каріопікноз. Рідше зустрічаються недиференційовані нейроцити, а також нейрони з морфологічними змінами зі сторони органел.

Висновок. Отже у м'язовому-кишковому сплетенні дванадцятипалої кишки в інтактних тварин переважають незмінені нейроцити, що становить 79,50\%. Серед змінених частіше виявляються нервові клітини із зворотними змінами - $18 \%$, і лише поодинокі з них мають незворотній характер - 2,5\%. Ступінь змін нейронів $\left(\mathrm{C}_{3}\right)$ дорівнює $40,23 \%$.

\section{Література:}

1. Хочанский Д.Н., Макарова О.В. Современные представления о структуре и функции энтеральной нервной системы. Морфологические ведомости. 2015. № 1. С. 106-117.

2. Антонюк О.П., Макар Б.Г., Олійник І.Ю. Розвиток інтрамуральних вузлів і васкуляризація стінок стравоходу та тонкої кишки. Український морфологічний альманах. 2012. Т. 10, № 4. С. 3-7.

3. Тибінка А.М. Характеристика міжм'язового нервового сплетіння кишечника у курей із різною типологією автономних впливів. Вісник ДАЕУ. Порівняльна морфологія. 2008. Т. 2, № 1 (21). С. 151-154.

4. Predrag Mandic, Tatjana Filipovic, Milos Gasic, Natasa DjukicMacut, Milan Filipovic, Ivan Bogosavljevic. Quantitative morphometric analysis of the myenteric nervous plexus ganglion structures along the human digestive tract. Vojnosanit Pregl. 2016; 73(6): 559-565.

5. Воробель, М. Д. Морфологические особенности межмышечного нервного сплетения кишечника. Актуальные проблемы современной медицины и фармации 2015: сб. тез. докл. 69-й науч.-практ. конф. студентов и молодых ученых с междунар. участием / под ред. О. К. Кулаги, Е. В. Барковского. 2015. С. 1035. 